\title{
Students' Decisions to Use an eLearning System: A Structural Equation Modelling Analysis
}

\author{
doi:10.3991/ijet.v4i4.928 \\ M.M. Abbad ${ }^{1}$, D. Morris ${ }^{2}$, A. Al-Ayyoub ${ }^{3}$, J.M. Abbad ${ }^{4}$ \\ ${ }^{1}$ Bahrain University, Mnamah, Bahrain, ${ }^{2}$ Coventry University, Coventry, UK \\ ${ }^{3}$ Dar Al-Uloom Colleges, Al-Riyadh, SA, ${ }^{4} \mathrm{Al}$ al-Bayt University, Mafraq, Jordan
}

\begin{abstract}
This research investigates and identifies some of the major factors affecting students' adoption of an elearning system at the Arab Open University in Jordan. Elearning adoption is approached from the information systems acceptance point of view. An extended version of the Technology Acceptance Model (TAM) was developed to investigate the underlying factors that influence students' decisions to use an e-learning system. The proposed model extends previous work by include actual system use as a dependent variable in addition to intentions to use. The model was estimated using Structural Equation Modelling (SEM). The final model derived from this study indicated that beliefs about usefulness and ease of use partially mediate the relationship between external factors and intention to use and actual use of e-learning systems.
\end{abstract}

Index Terms - Adoption, E-learning, TAM, and SEM.

\section{INTRODUCTION}

The Internet has been growing at an exponential rate. There are approximately 1.5 billion Internet users around the world and approximately 42 million Internet users in the Middle East [1]. The global growth rate of Internet users between 2000 and 2008 was $290 \%$ compared to $1,177 \%$ in the Middle East. The Internet and the web have transformed the business environment and the way people communicate. In higher education institutions, adoption of the Internet and web-enabled systems for learning has been rapidly increasing. For example, the Open University (OU) has become the UK's largest university with over 200,000 students [2]. This appears to be due, in part, to the flexibility and portability of the delivery of web-based learning. However, there is a lack of empirical examination of the adoption of web-based learning systems [3]. Successful adoption requires a solid understanding of user acceptance processes and how to entice students to accept these technologies [4]. Much research has addressed the antecedents of technology use, but the overwhelming majority of the studies have focused on users in developed countries [5]. Developing regions of the world have much to gain from the Internet and IT in general, but have received relatively little research attention [6], even though cultural differences may influence technology use [7]. Jordan is witnessing rapid developments in information technology. The total number of Internet users increased from 127,300 in 2000 to 796,900 in 2007 and the penetration rate grew by $526 \%$ [1]. The vision of HM King Abdullah II that "Jordan will become an IT hub for the region" [8] has been a rallying call to government ministries and agencies, private sector associations and companies, non-governmental bodies and individuals within the soci- ety to pull together to exploit IT for the future benefit of all citizens. In addition, the King expressed the country's aspiration to become a regional leader in e-learning. "This is not just for Jordan", said the King "If we are successful here, we'll be doing it for the rest of the Middle East" [9]. The Arab Open University, (AOU) was founded by Prince Talal bin AbdulAziz under the umbrella of the AGFUND (Arab Gulf Program for United Nations Development Organizations) and is headquartered in Kuwait, but one of its first branches was founded in Jordan in 2002.

\section{TEChNOLOGY ACCEPTANCE MOdel (TAM)}

The problem of identifying and measuring the factors [10] that determine computer usage has inspired many researchers in the management information system (MIS) community during the past two decades. TAM is an intention-based model that was developed specifically for explaining and predicting user acceptance of computer technology [11] and has been widely applied in a variety of settings [12, 13, 14, 15, 16, 17, 18, 19]. Although the TAM initially focused on system usage in the workplace, researchers have employed the model to help understand website usage [20,21] and e-learning [22]. TAM has probably generated more empirical evidence in explaining technology acceptance than any other approach [19], and previous research has suggested it could be an appropriate model to examine a student's acceptance of e-learning applications over a period of time [16]. TAM is an adaptation of the theory of reasoned action (TRA), but specifically tailored for modeling user acceptance of information systems [23]. According to TRA, beliefs influence attitudes, which lead to intentions, which then generate behavior. Perceived usefulness (PU) is defined as "the prospective probability that using a specific application system will increase his or her job performance within an organizational context". Perceived ease of use (PEOU) refers to "the degree to which the prospective user expects the target system to be free of effort" [23]. However, perceived ease of use and perceived usefulness may not fully reflect the users' intention to adopt IT, and researchers need to address how other factors affect usefulness, ease of use, and user acceptance [11]. These factors are likely to vary with the technology, target users and context, which include external influences [13].

\section{INDEPENDENT VARIABLES}

\section{A. Subjective Norms (SN)}

According to the TRA model, in addition to the individuals' perceptions and beliefs, social influences may affect behavior [26]. In some studies, social influences are 
ANALYSIS

equated to subjective norms and refer to other people's opinions, superiors' influence, and peer pressure [27]. In others it is argued that people might use a system to comply with others' mandates rather than their own feelings and beliefs [28]. Subjective norms have been found to play two separate and different roles: one as the antecedent of behavioral intention and the other as the antecedent of perceived usefulness. Empirical support for the relationship between social norms and behavior can be found in many studies $[20,29]$. In the e-learning context, there is evidence that SN influences the learner's satisfaction with and motivation for e-learning [30]. In addition, SN was a significant predictor of students' satisfaction [31]. Moreover social factors can enhance students' motivation and satisfaction [32]. In this study, subjective norms refer to a student's perception of opinions or suggestions of significant referents concerning his or her acceptance of an e-learning system at the AOU. SN can have a significant direct $[27,33,34]$ or indirect effect $[20]$ in predicting an individual's intention to use computer technology, and significantly influence perceived (system) usefulness [35]. Thus, we hypothesize:

H1: Subjective norms will have a positive effect on perceived usefulness of e-learning systems.

$\mathrm{H} 2$ : Subjective norms will have a positive effect on the intention to use e-learning systems.

\section{B. Internet Experience (IE)}

Research studies suggest that prior experience is important in an individual's acceptance of IT [36]. Prior experience may strongly influence intention to use and usage of a specific system through perceived ease of use [37] and through perceived usefulness [38]. In the context of elearning, a student's course website use tends to be greater when the site is viewed as being useful and easy to use [39]. Thus, as student experience with a technology increases, they perceive it to be easier to use and more useful, and therefore, are more likely to use it. Thus, we hypothesize:

H3: Internet experience will have a positive effect on ease of use of the e-learning systems.

H4: Internet experience will have a positive effect on perceived usefulness of the e-learning systems.

\section{System Interactivity (SI)}

Research suggests that system characteristics can influence the intention to use and usage behavior of the system. Arguably, the main advances in distance education will come from technology that promotes increased learner interaction [40]. As Paloff and Pratt note, "the key elements of learning processes are the interactions among students themselves, the interactions between faculty and students, and the collaboration in learning that results from these interactions" [41]. A web-based learning (WBL) environment should combine both synchronous and asynchronous communication to support various elements such as text, graphics, audio and video messages [42]. For example, students' grades have been found to be highly correlated with students' interactivity [43]. We hypothesize:

H5: System interactivity will have a positive effect on ease of use of the e-learning systems.

H6: System interactivity will have a positive effect on perceived usefulness of the e-learning systems.

\section{Self-Efficacy (SE)}

Self-efficacy is an individual's belief in their capability to adopt certain behaviors or it is one's personal beliefs about his or her ability to perform certain tasks successfully. Perceived self-efficacy refers to the beliefs in one's capability to organize and execute the courses of action required to produce a given accomplishment or outcome and originates from various sources including performance accomplishments, vicarious experience, verbal persuasion, and psychological states $[44,45]$. Self-efficacy is an antecedent of perceived ease of use and object use ability $[28,46]$. Computer self-efficacy is a significant determinant of behavioral intention to use information technology $[47,48,49]$. Self-efficacy is a major predictor of both intention and behavior after controlling for intention [50]. In the e-learning context, self-efficacy is interpreted as one's self-confidence in his or her ability to perform certain learning tasks using an e-learning system. A student who has a strong sense of his or her capability in dealing with an e-learning system has a more positive perception of ease of use and usefulness and he or she is more willing to accept and use the system. We hypothesize that:

H7: Self-efficacy will have a positive effect on ease of use of the e-learning systems.

H8: Self-efficacy will have a positive effect on perceived usefulness of the e-learning systems.

\section{E. Technical Support (TS)}

Technical support can be defined as people assisting the users of computer hardware and software products, which can include hotlines, online support service, machinereadable support knowledge bases, faxes, automated telephone voice response systems, remote control software and other facilities [51]. Technical support is one of the important factors in the acceptance of technology for teaching $[52,53,54]$ and in user satisfaction [55]. Training and prior computer experiences can have a significant impact on system use [56]. Many failed e-learning projects did not have access to technical advice and support $[57,58]$. If technical support is lacking, e-learning will not succeed [39]. Recently, the TAM has been extended to include technical support as an independent variable in explaining user acceptance of WebCT [3]. The results showed that technical support has a significant direct effect on perceived ease of use and usefulness, while perceived ease of use and usefulness are the dominant factors affecting the attitude of students using WebCT. We hypothesize that:

H9: Technical support will have a positive effect on ease of use of the e-learning systems.

H10: Technical support will have a positive effect on perceived usefulness of the e-learning systems.

\section{F. Other Factors}

The TAM model posited the beliefs of perceived usefulness (PU) and perceived ease of use (PEOU) as determinant factors of the intention to use IT. IT usage intentions, in turn, are assumed to directly influence actual use. Therefore, we hypothesize:

H11: Perceived ease of use will have a positive effect on perceived usefulness of the e-learning systems.

H12: Perceived ease of use will have a positive effect on the intention to use the e-learning systems. 


\section{ANALYSIS}

H13: Perceived usefulness will have a positive effect on the intention to use the e-learning systems.

H14: Intention to use will have a positive effect on the actual use of e-learning systems.

\section{METHODS}

\section{A. Research instrument}

A seven-point scale was employed to measure TAM variables. This type of scale is argued to meet reliability and validity criteria $[11,20,23]$. The TAM variables were measured using Likert-type (agree-disagree) rating formats. The research instrument (questionnaire) used 36 items (see Table 4) to measure the eight variables shown in Table 1. One further item was used to obtain a selfreported measure (frequency of use) of actual system use. Frequency of using a system is typical of the usage metric routinely used in MIS research [23,59]. Full details of the methods used to generate questionnaire items and the approach employed to construct the research instrument can be found elsewhere [59].

\section{B. Subjects}

Since Arabic is the main language spoken in Jordan, the empirical study was conducted in the Arabic language. The Arabic questionnaire was pilot tested using Arab Open University students. Participants in the study consisted of undergraduate students who were taking the last lecture of the first basic computer literacy classes at the Arab Open University (AOU) in Jordan. The courses made substantial use of WebCT. Participation in this study was voluntary, and 486 of 654 students (74.3\%) who were enrolled in these classes agreed to take part. Sixteen questionnaires with more than $5 \%$ of missing data were identified and deleted. Thus, 470 questionnaires were included in the analysis. The sample was 470 cases, the analysis conducted on 36 items; the ratio of items to cases was 1:13. The majority of respondents were female (68\%). Participants were drawn from different faculties, a little less than half $(45.5 \%)$ of the students were studying in the Faculty of Educational Studies. Also, a little less than half $(46 \%)$ of the students were full-time workers, the other students were classified as not working $(42.5 \%)$ and part-time workers $(11.5 \%)$. The student population was not therefore full-time, young and campus-based. The proportion of students who had computers at home was $81 \%$, and $44.7 \%$ had an Internet connection at home. $44 \%$ of the students stated that they had more than two years' Internet experience; $15 \%$ of students had never used the Internet prior to the course.

\section{DATA ANALYSIS AND RESUltS}

\section{A. Analysis of Measurement Validity}

Measurement validity in terms of reliability and construct validity was evaluated. The measures of reliability ranged from 0.802 to 0.877 (see Table 1); all are in the acceptable range (0.7 to 1.0$)$ [60]. As shown in Table 2, factor correlation coefficients, ranging from 0.389 to 0.797 , all indicated that the constructs were correlated yet statistically distinct and, therefore, provided a strong evidence of discriminant validity. Generally, a factor correlation of 0.85 or higher indicates that two factors might be the same factor in measurement terms. Correlations greater than 0.3 for the sample size of 470 used in the analysis are statistically significant at the 0.01 level. An inspection of the correlation matrix revealed that all of the inter-item correlations were significant at the 0.01 level. The items associated with a particular measure correlated more highly with each other than with items associated with other measures in the model. As a result, the convergent and discriminant validity of the measurement can be demonstrated. Exploratory factor analysis (EFA) was used as an initial step to be sure that all the a priori factors differ from each other. This can be assessed through principal component analysis (PCA). Using VARIMAX rotation, PCA was used in an attempt to reconstruct five composite factors. When interpreting the rotated factor pattern, an item is said to load on a factor if the factor loading is 0.4 or greater [60]. Using this criterion, the rotated pattern matrix was examined for items that did not load on a factor with other items from the same scale. Items that crossloaded on multiple factors were also examined and deleted. The PCA showed five factors were extracted. The results of the PCA for each of the factors are given in Table 3 . These results show that the loading of individual items on the factor exceeded 0.4 [60]. In Table 3, all factor loadings (see the numbers in bold) were greater than 0.5 and no cross loading on multiple factors exceeded 0.5 . As a result, all the factors added to TAM as external factors that may affect students' adoption of e-learning system were extracted. PCA was used again in an attempt to reconstruct all factors (external and endogenous) together. The results of the PCA for each of the constructs are given in Table 4. As a result, eight distinct factors in the proposed model were extracted.

\section{B. Overall Model Testing Results}

An analysis of the standardized residual for the initial model suggests that the maximum residual is for the covariance between the measured variables IE (and particularly the sub-measure represented by item IE3) and AU (through PU) followed by IE and AU (through PEU). Their values are 5.023 and 4.125 respectively, values ( $>$ 4.0) which indicate a structural relationship in the form of a direct path from IE to AU. In the initial model, the relationship between these two constructs is accounted for only by the indirect relationships:

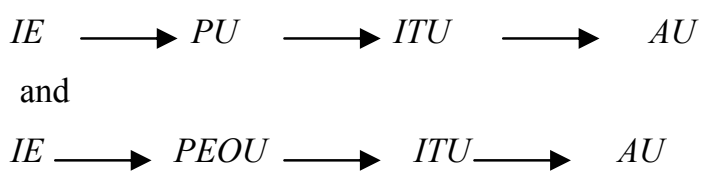

Based on these results, the initial model was modified to include a direct arrow from IE to AU (see Figure 2). The commonly used measures of model fit, based on results from an analysis of the modified model, are summarized in Table 5. All goodness-of-fit statistics are in the acceptable ranges and indicate acceptable fit to the data. The estimated modified model can be expressed by the following structural equations with non-standardized regression coefficients:

$$
\begin{aligned}
& \text { (1) } P U=0.476 P E U+0.167 S N-0.102 \mathrm{IE}+ \\
& 0.064 \mathrm{SI}+0.146 \mathrm{SE}+0.194 \mathrm{TS} \\
& R^{2}=0.613 \quad \text { Error variance }=0.387
\end{aligned}
$$


(2) $P E U=0.191 I E+0.001 S I+0.659 S E+0.057$ $T S$

$$
R^{2}=0.580 \quad \text { Error variance }=0.42
$$

(3) $I T U=0.434 P U+0.456 P E U+0.129 S N$

$R^{2}=0.75$ Error variance $=0.25$

(4) $A U=0.434 I T U+0.456 I E$

$R^{2}=0.211$ Error variance $=0.789$

In the above equations, the regression coefficients in each structural equation of the model are the path values. The error variance represents the proportion of variance in intention to use that was unexplained by perceived ease of use, perceived usefulness, and subjective norms. The critical ratios (or t-values, obtained by dividing the path values by their standard errors) in Table 6 were used to test whether the path values were significantly different from zero. The path values were significantly different from zero if the critical ratio exceeded 1.96 and thus the significance level was less than 0.05 . As shown in Table 7, nine of thirteen paths were significant.

\section{Hypothesis Testing}

The discussion in Section 3 above generated fourteen individual hypotheses. A particular individual hypothesis is supported by our results if the direct path coefficients linking the two variables in question are statistically significant. For example, the first hypothesis was expressed as:

H1: Subjective norms will have a positive effect on perceived usefulness of e-learning systems.

The results of testing this hypothesis are shown in the top data line of Table 6; the hypothesis is supported by the statistical evidence. Results for hypotheses 2 to 13 are shown in subsequent rows. Hypothesis 14 is supported by equation 4 which shows a significant and positive relationship between actual use of the e-learning system and intention to use. However, if we disaggregate the total effects shown by the coefficients on the independent variables in equation 4 into direct and direct effects (not shown here, but covered in detail elsewhere, see [59]), the major components of the relationship between AU and ITU are indirect effects, although the direct effect is statistically significant. Overall, however, equation 4 only explains $21 \%$ of the variation in actual use of the e-learning system.

\section{DISCUSSION}

The results of estimating the modified model demonstrate the importance of perceived ease of use and perceived usefulness in mediating the relationships between external factors and intention to use e-learning systems. The study explained $75 \%$ of the variance in intention to use and $21 \%$ of variance in actual use of the system. The final model indicated that beliefs in the usefulness and ease of use partially mediate the relationship between external factors and intention to use and actual use of elearning systems. The results show that self-efficacy is an important determinate in perceived ease of use [46] and self-efficacy showed a strong direct effect on perception of ease of use [11]. The results also indicated that selfefficacy had the strongest indirect effect upon students' intention to use e-learning, and this is consistent with some other prior studies $[27,37,62]$. The results show that a student's prior Internet experience influences perceived usefulness, perceived ease of use and actual use of an elearning system. However, unexpectedly, the relationship between experience of using the Internet and perceived usefulness of the e-learning system was negative, although not statistically significant. A possible explanation for this relationship is that students with high Internet experience were looking for more facilities and benefits from using the e-learning system, which is they had higher expectations. The relationship between Internet experience and actual use of the e-learning system was stronger than the relationship between intention to use and actual use. This result was consistent with that the notion that actual use requires skills and resources such as those acquired using the Internet [62] or that students who tend to use IT in other contexts will also tend to use it for study purposes. System interactivity is students' perceptions of a system's ability to provide interactive communications between instructor and students and among students. There was no evidence to support the initial hypothesis that system interactivity would be a positive factor would positively influence students' perceptions of how easy an e-learning system would be to use or how useful it might be in their studies. As a consequence system interactivity did not play any (indirect) role in influencing either intentions to use or actual use of the system. From the results, technical support (such as training and support) was found to have a direct effect on perceived usefulness and an indirect effect on intention to use. This showed the importance of user support and training in influencing the perceptions of students. The model was much more successful in explaining the variation in intentions to use the e-learning system than it was in explaining actual use. This could be due to one of three reasons. Firstly, there may be a gap between (good) intentions and action; that is intentions are not always translated into action. This is a very a familiar phenomenon and may well be an inherent part of human nature. One explanation of this may be that there may be intervening variables in the gap between intentions and actions which mediate the relationship; lack of time may be one. Secondly, the model may omit variables which are important in determining actual use. The most prominent of these might be the availability of suitable access to the system. Thirdly, ex ante intentions or even early activity may not be a good guide to continuance behavior. In general it is well known that initial enthusiasms for new systems are often dampened by the realities of actual use and that users often revert to existing ways of doing things after a short trial period. The problem of potential omitted variables is a limitation to the current work and provides potentially fruitful avenues for further research. The inclusion of additional relevant factors could result in a model that has more explanatory power. A second area which could provide improvements is in the measurement of some of the variables. In previous research behavioral intention is the closest construct used as a surrogate for elearning usage. The model explained a significant portion of the variance $(75 \%)$ in behavioral intention to use the system, but only a small portion of the variance $(21 \%)$ in actual use. In this study, a self-reported measure provided by respondents was used to measure actual use; however, this might not be the best way to measure actual use. 


\section{Students’ Decisions to Use An eLEARning System: A Structural Equation Modelling ANALYSIS}

\section{CONCLUSIONS}

This research has extended the TAM in a previously unexplored direction with positive results. Most of the relationships between the constructs postulated in the model are well supported. This provides further evidence of the appropriateness of applying TAM to measure the acceptance of e-learning systems. In overall terms the educational technology literature does not always make great use of models and approaches drawn from outside the mainstream educational discourse. Whilst the TAM does not hold all the answers or even many of them, it can provide a useful perspective for advancing our understanding of why students make use of e-learning systems and the ways in which educators might improve the takeup of e-learning opportunities by students. To encourage students' intention and use of the system, university administrators, designers, and instructors might focus on creating ease of use and usefulness perceptions and creating social expectations regarding usage. It is essential for universities to provide effective student support, including training courses, to encourage students to use the system. On the other hand the approach exemplified in this work, that of applying a systems point of view to e-learning, ignores the major pedagogic and other educational debates in the e-learning arena. Issues of student and tutor engagement, teaching style, interactivity in course delivery, the quality of the content and the design of the course and are all major influences on students' use of e-learning systems. None of these form part of the model discussed here.

\section{REFERENCES}

[1] Internet World Stats (2008) Usage and population statistics. [online] available from $<\mathrm{http} / /$ internetworldstats.com $/$ stats.htm $>$ [10 August 2008].

[2] OU (2008) E-learning at the Open University. [online] Open University available from <http://www3.open.ac.uk/courses/ about/index.shtml $>$ [10 August 2008].

[3] Ngai, E.W.T., Poon, J.K.L. and Chan, Y.H.C. (2007) 'Empirical examination of the adoption of WebCT using TAM.' Computers and Education 48, (2) 250-267. (doi:10.1016/j.compedu. 2004.11.007)

[4] Saadé, R. and Bahli, B (2005) 'The impact of cognitive absorption on perceived usefulness and perceived ease of use in on-line learning: an extension of technology acceptance model.' Information and Management 42, (2) 317-327. (doi:10.1016/j.im.2003.12.013)

[5] Mahmood, M. A., Hall, L. and Swanberg, D. L. (2001) 'Factors Affecting Information Technology Usage: A Meta-Analysis of the Empirical Literature.' Journal of Organizational Computing and Electronic Commerce 11, (2) 107-130. (doi:10.1207/S1532 7744JOCE1102_02)

[6] Hasan, H. and Ditsa, G. (1998) 'The Impact of Culture on the Adoption of IT: An Interpretive Study.' Journal of Global Information Management 7, (1) 5-15.

[7] Veiga, J. F., Floyd, S. and Dechant, K. (2001) 'Towards modeling the effects of national culture on IT implementation and acceptance.' Journal of Information Technology 16, (1) 145-158. (doi:10.1080/02683960110063654)

[8] ELCU (2002) Jordan will become IT hub for the region. ELearning Coordination Unit: Ministry of Education, Jordan [online] Available from <http://www.moe.gov.jo/learning/ vision_11.htm $>$ [18 January 2005].

[9] WEF (2003) World Economic Forum: Report 2003. [online] Available from $<$ http://www.weforum.org $>$ [21 October 2005].

[10] Whetten, D. (1989) 'What constitutes a theoretical contribution?' Academy Management Review 14, (4), 490-495. (doi:10.2307/258554)
[11] Davis, F.D. (1989) 'Perceived usefulness, perceived ease of use, and user acceptance of information technology.' MIS Quarterly 13, (3) 319-340. (doi:10.2307/249008)

[12] Gefen, D. and Straub, D. (2000) 'The relative importance of perceived ease of use in IS adoption: A study of e-commerce adoption.' Journal of the Association for Information Systems 1, (8) 130.

[13] Gefen, D. (2003) 'TAM or just plain habit: A look at experienced online shoppers.' Journal of End User Computing15, (3) 1-13.

[14] Stoel, L. and Lee, K. H. (2003) 'Modeling the effect of experience on the student acceptance of web-based courseware.' Internet research: Electronic Network Applications and Policy 13, (5) 364374. (doi:10.1108/10662240310501649)

[15] Adams, D. A., Nelson, R. R. and Todd, P. A. (1992) 'Perceived usefulness, ease of use, and usage of information.' MIS Quarterly 16, (2) 227-247. (doi:10.2307/249577)

[16] Dishaw, M. T. and Strong, D. M. (1999) 'Extending the technology acceptance model with task-technology fit constructs.' Information and Management 36, (1) 9-21. (doi:10.1016/S03787206(98)00101-3 )

[17] Hu, P. J., Chau, P. Y. K., Sheng, O. R. L. and Tam, K. Y. (1999) 'Examining the technology acceptance model using physician acceptance of telemedicine technology.' Journal of Management Information Systems 16, (2) 91-112.

[18] Venkatesh, V. and Davis, F. (2000) 'A theoretical extension of the technology acceptance model: four longitudinal field studies.' Management Science 46, (2) 186-204. (doi:10.1287/mnsc.46.2. 186.11926)

[19] Van Slyke, C., Belanger, F. and Haynes, J. (2003) 'The impact of interface complexity on elderly users: An extension of the technology acceptance model.' Paper presented at the SAIS, Savannah, GA.

[20] Teo, T., Lim, V. and Lai, R. (1999) 'Intrinsic and extrinsic motivation in Internet usage.' Omega International Journal of Management 27, (1) 25-37.

[21] Moon, J. and Kim, Y. (2001) 'Extending the TAM for a World Wide Web Context.' Information and Management 38, (4) 217 231. (doi:10.1016/S0378-7206(00)00061-6)

[22] Carswell, A. D. and Venkatesh, V. (2002) 'Learner outcomes in an asynchronous distance educational environment.' International Journal of Human-Computer Studies 56, (5) 475-494. (doi:10.1006/ijhc.2002.1004)

[23] Davis, F. D. (1986) A technology acceptance model for empirically testing new end-user information systems: Theory and results. (Doctoral dissertation, Sloan School of Management, Massachusetts Institute of Technology).

[24] Hong, W., Thong, J.Y.L., Wong, W.M. and Tam, K.Y. (2001) 'Determinants of user acceptance of digital libraries: an empirical examination of individual differences and system characteristics.' Journal of Management Information Systems 18, (3) 97-124.

[25] Chau, P.Y.K. (1996) 'An empirical assessment of a modified technology acceptance model.' Journal of Management Information Systems 13, (2) 185-204.

[26] Ajzen, I. (1985) From intention to actions: A theory of planned behavior. New York: Springer Verlag.

[27] Taylor, S. and Todd, P.A. (1995) 'Understanding information technology usage: a test of competing models.' Information Systems Research 6, (2) 144-176. (doi:10.1287/isre.6.2.144)

[28] Davis, F.D., Bagozzi, R.P. and Warshaw, P.R. (1989) 'User acceptance of computer technology: a comparison of two theoretical models.' Management Science 35, (8) 982-1003. (doi:10.1287/mnsc.35.8.982)

[29] Tornatsky, L.G. and Klein, K.J. (1982) 'Innovation characteristics and innovation adoption-implementation: a meta-analysis of findings.' IEEE Transactions on Engineering Management,(1) 28-45.

[30] Kim, K., Liu, S. and Bonk, C.J. (2005) 'Online MBA students' perceptions of online learning: Benefits, challenges, and suggestions.' The Internet and Higher Education 8, (4) 335-344. (doi:10.1016/j.iheduc.2005.09.005)

[31] Gunawardena C.N. and Zittle, F.J. (1997) 'Social presence as a predictor of satisfaction within a computer-mediated conferencing environment.' American Journal of Distance Education 11, (3) 826. (doi:10.1080/08923649709526970) 


\section{Students’ Decisions to Use An eLEARning System: A Structural Equation Modelling ANALYSIS}

[32] Frith, K. H. (2002) Effect of conversation on nursing student outcomes in a Web-based course on cardiac rhythm interpretation. Doctoral dissertation, Georgia State University, Atlanta.

[33] Ajzen, I. (1988) Attitudes, personality, and behavior. Chicago, IL: The Dorsey Press.

[34] Mathieson, K. (1991) 'Predicting user intentions: comparing the Technology Acceptance Model with the theory of planned behavior.' Information Systems Research 2, (3) 173-191. (doi:10.1287/isre.2.3.173)

[35] Lee, Y.C. (2006) 'An empirical investigation into factors influencing the adoption of an e-learning system.' Online Information Review 30, (5) 517-541. (doi:10.1108/14684520610706406)

[36] Igbaria, M., Gamers, T. and Davis, G.B. (1995) 'Testing the determinants of micro-computer usage via a structural equation model.' Journal of Management Information Systems 11, (4) 87 114.

[37] Agarwal, R. and Prasad, J. (1999) 'Are individual differences germane to the acceptance of new information technologies?' $D e-$ cision Sciences 30, (2) 361-91. (doi:10.1111/i.1540-5915. 1999.tb01614.x)

[38] Jiang, J.J., Hsu, M.K., Klein, G. and Lin, B. (2000) 'E-commerce user behavior model: an empirical study.' Human Systems Management 19 , (4) 265-276.

[39] Selim, H.M. (2003) 'An empirical investigation of student acceptance of a course websites.' Computers and Education 40, (4) 343 360. (doi:10.1016/S0360-1315(02)00142-2)

[40] Bates, A. W. (1991) 'Third generation distance education: The challenge of new technology.' Research in Distance Education 3, (2) $10-16$.

[41] Palloff R.M. and Pratt, K. (1999) Building learning communities in cyberspace: Effective strategies for the online classroom. Jossey-Bass Publishers, San Francisco, CA.

[42] Alhabshi, A.O. (2002) 'E-learning: a Malaysia case study.' $\mathrm{Na}$ tional Institute of Public Administration (INTAN), Bukit Kiara Main Campus, Kuala Lumpur, Malaysia, paper presented at the Africa-Asia Workshop on Promoting Co-operation in Information and Communication Technologies Development.

[43] Poon, W., Low, K. L. and Yong, D. G. (2004) 'A study of Webbased learning (WBL) environment in Malaysia.' The International Journal of Educational Management 18, (6) 374-385. (doi:10.1108/09513540410554031)

[44] Bandura, A. (1986) Social Foundations of Thought and Action: A Social Cognitive Theory. Englewood Cliffs: NJ: Prentice Hall.

[45] Bandura, A. (1997) 'Self-efficacy: toward a unifying theory of behavioral change.' Psychological Review 82, (2) 191-215.

[46] Venkatesh, V. and Davis, F.D. (1996) 'A model of the antecedents of perceived ease of use: development and test.' Decision Sciences 27, (3) 451-481. (doi:10.1111/j.1540-5915.1996.tb01822.x )

[47] Compeau, D.R. and Higgins, C.A. (1995) 'Computer self-efficacy: Development of a measure and initial test.' Management Information Systems Quarterly 19, (2) 189-211. (doi:10.2307/249688)

[48] Hill, T., Smith, N.D. and Mann, M.F. (1987) 'Role of efficacy expectations in predicting the decision to use advanced technologies: The study of computers.' Journal of Applied Psychology 72, (2) 307-313. (doi:10.1037/0021-9010.72.2.307)

[49] Venkatesh, V. and Davis, F. D. (1994) 'Modeling the Determinants of Perceived Ease of Use.' Proceedings of the International Conference on Information Systems, Vancouver, BC, 213-228.
[50] Lim, C. K. (2000) Computer self-efficacy, academic self-concept and other factors as predictors of satisfaction and future participation of adult learners in Web-based distance education. Dissertation Abstracts International, 61, 02A. (UMI No. 9962612).

[51] Ralph, W. (1991) The art of computer technical support. California: Peachipt Press.

[52] Sumner M. and Hostetler, D. (1999) 'Factors influence the adoption of technology in teaching.' Journal of Computer Information Systems 40, (1) 81-87.

[53] Hofmann, D.W. (2002) 'Internet-based distance learning in higher education.' Tech Directions 62, (1) 28-32.

[54] Williams, P. (2002) 'The Learning Web: the development, implementation, and evaluation of Internet-based undergraduate materials for the teaching of key skills.' Active Learning in Higher Education 3, (1) 40-53. (doi:10.1177/1469787402003001004)

[55] Mirani R. and King, W.R. (1994) 'Impacts of end-user and information center characteristics on end-user computing support.' Journal of Management Information Systems 11, (1) 141-166.

[56] Vandenbosch, B. and Higgins, C. (1995) 'Executive support systems and learning: a model and empirical test.' Journal of Management Information Systems 12, (2) 99-130.

[57] Alexander, S. and McKenzie, J. (1998) An Evaluation of Information Technology Projects in University Learning. Department of Employment, Education and Training and Youth Affairs, Canberra: Australian Government Publishing Services.

[58] Soong, M.H.B., Chan H.C., Chua, B.C. and Loh, K.F. (2001) 'Critical success factors for on-line course resources.' Computers and Education 36, (2) 101-120. (doi:10.1016/S03601315(00)00044-0)

[59] Abbad, Muneer (2009) Factors Affecting Students' Adoption of Elearning Systems in Jordanian Universities. PhD Thesis, Coventry University.

[60] Nunnaly, Y.J. (1978) Psychometric theory. McGraw Hill, New York.

[61] Davis, F.D. (1993) 'User acceptance of information technology: system characteristics, user perceptions and behavioral impacts.' International Journal of Man-Machine Studies 38, (1) 475-87. (doi:10.1006/imms.1993.1022)

[62] Doll, W.J., Hendrickson, A and Deng, X (1998). 'Using Davis's perceived usefulness and ease-of-use instruments for decision making: a confirmatory and multi-group invariance analysis.' Decision Science 29, (4) 839-869. (doi:10.1111/j.1540-5915. 1998.tb00879.x)

\section{AUTHORS}

M.M. Abbad is with Bahrain University/ Information System, Mnamah, Bahrain.

D. Morris is with Coventry University/ Higher Education Development, Coventry, UK.

A. Al-Ayyoub is with Dar Al-Uloom Colleges/ CEIT, Al-Riyadh, SA.

J.M. Abbad is with Al al-Bayt University/ Finance and Banking, Mafraq, Jordan.

Submitted 12 May 2009. Published as resubmitted by the authors on 18 November 2009. 
ANNEX

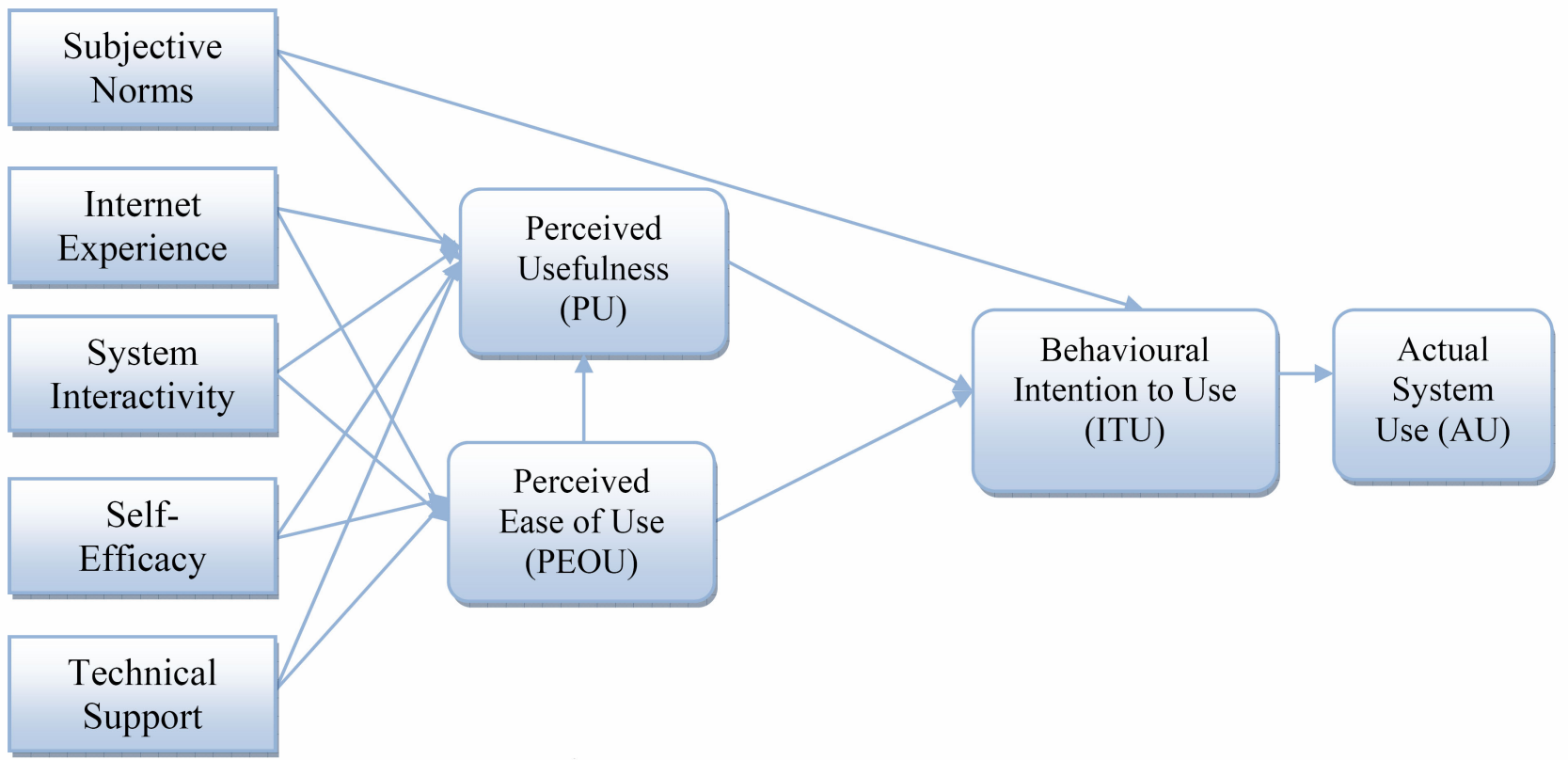

Figure 1. Initial Research Model

TABLE I.

ITEMS AND CRONBACH'S ALPHA

\begin{tabular}{|l|l|c|}
\hline \multicolumn{1}{|c|}{ Factor } & \multicolumn{1}{|c|}{$\begin{array}{c}\text { Measurement } \\
\text { Items }\end{array}$} & $\begin{array}{c}\text { Reliability } \boldsymbol{\alpha} \\
(>\mathbf{0 . 7})\end{array}$ \\
\hline $\begin{array}{l}\text { Perceived Usefulness } \\
\text { (PU) }\end{array}$ & $\begin{array}{l}\text { PU1 } \\
\text { PU3 } \\
\text { PU4 }\end{array}$ & 0.847 \\
\hline $\begin{array}{l}\text { Perceived Ease of Use } \\
\text { (PEOU) }\end{array}$ & $\begin{array}{l}\text { PEU3 } \\
\text { PEU4 } \\
\text { PEU6 }\end{array}$ & 0.874 \\
\hline $\begin{array}{l}\text { Intention to Use } \\
\text { (ITU) }\end{array}$ & ITU1 & \\
\hline $\begin{array}{l}\text { Subjective Norms } \\
\text { (SN) }\end{array}$ & ITU3 & \\
\hline $\begin{array}{l}\text { Internet Experience } \\
\text { (IE) }\end{array}$ & SN2 & 0.877 \\
\hline $\begin{array}{l}\text { System Interactivity } \\
\text { (SI) }\end{array}$ & SN4 & \\
\hline $\begin{array}{l}\text { IE2 } \\
\text { IE3 }\end{array}$ & SI1 & 0.844 \\
(SE) & SI2 & \\
\hline $\begin{array}{l}\text { Technical Support } \\
\text { (TS) }\end{array}$ & SE2 & 0.864 \\
\hline
\end{tabular}


TABLE II.

FACTOR CORRELATIONS

\begin{tabular}{|c|l|l|l|l|l|l|l|l|}
\hline & \multicolumn{1}{|c|}{ PEU } & \multicolumn{1}{c|}{ PU } & \multicolumn{1}{c|}{ ITU } & TS & \multicolumn{1}{c|}{ SE } & SI & IE & SN \\
\hline PEU & 1 & & & & & & & \\
\hline PU & 0.715 & 1 & & & & & & \\
\hline ITU & 0.797 & 0.791 & 1 & & & & & \\
\hline TS & 0.416 & 0.520 & 0.474 & 1 & & & & \\
\hline SE & 0.727 & 0.640 & 0.691 & 0.452 & 1 & & & \\
\hline SI & 0.491 & 0.541 & 0.585 & 0.519 & 0.638 & 1 & & \\
\hline IE & 0.598 & 0.441 & 0.516 & 0.438 & 0.600 & 0.477 & 1 & \\
\hline SN & 0.508 & 0.551 & 0.558 & 0.389 & 0.570 & 0.650 & 0.456 & 1 \\
\hline
\end{tabular}

TABLE III.

COMPONENT MATRIX (EXTERNAL FACTORS)

\begin{tabular}{|c|c|c|c|c|c|}
\hline \multirow[t]{2}{*}{ Item } & \multicolumn{5}{|c|}{ Component } \\
\hline & 1 & 2 & 3 & 4 & 5 \\
\hline TS1 & .154 & .616 & .316 & .234 & .028 \\
\hline TS2 & .106 & .794 & .115 & .125 & .127 \\
\hline TS3 & .144 & .840 & .103 & .091 & .079 \\
\hline TS4 & .148 & .725 & .093 & .197 & .229 \\
\hline TS5 & .281 & .501 & .074 & .403 & .250 \\
\hline IE1 & .340 & .109 & .125 & .222 & .703 \\
\hline IE2 & .205 & .182 & .162 & .097 & .835 \\
\hline IE3 & .176 & .182 & .189 & .132 & .851 \\
\hline SN1 & .282 & .257 & .667 & .133 & .281 \\
\hline $\mathrm{SN} 2$ & .191 & .185 & .817 & .080 & .122 \\
\hline SN3 & .195 & .099 & .824 & .231 & .122 \\
\hline SN4 & .196 & .092 & .696 & .388 & .109 \\
\hline SI1 & .214 & .223 & .217 & .786 & .118 \\
\hline SI2 & .186 & .216 & .193 & .798 & .109 \\
\hline SI3 & .215 & .208 & .243 & .709 & .214 \\
\hline SE1 & .587 & .304 & .245 & .352 & .203 \\
\hline SE2 & .729 & .206 & .103 & .209 & .314 \\
\hline SE3 & .801 & .172 & .176 & .152 & .222 \\
\hline SE4 & .749 & .093 & .203 & .289 & .103 \\
\hline SE5 & .803 & .144 & .320 & .039 & .170 \\
\hline Eigenvalue & 8.871 & 1.699 & 1.531 & 1.186 & 1.093 \\
\hline $\begin{array}{c}\text { Cum. Variance } \\
\text { Explained } \%\end{array}$ & 44.357 & 52.854 & 60.509 & 66.440 & 71.908 \\
\hline
\end{tabular}

Note: Factor loadings in bold 
TABLE IV

COMPONENT MATRIX (ALL FACTORS)

\begin{tabular}{|c|c|c|c|c|c|c|c|c|}
\hline \multirow[t]{2}{*}{ Item } & \multicolumn{8}{|c|}{ Component } \\
\hline & 1 & 2 & 3 & 4 & 5 & 6 & 7 & 8 \\
\hline PU1 & .701 & .217 & .184 & -.001 & .250 & .160 & .140 & .129 \\
\hline PU2 & .786 & .084 & .157 & .195 & .138 & .130 & .186 & .150 \\
\hline PU3 & .755 & .203 & .239 & .202 & .157 & .166 & .009 & .123 \\
\hline PU4 & .710 & .189 & .226 & .105 & .140 & .102 & .071 & .198 \\
\hline PU5 & .673 & .371 & .021 & .239 & .165 & .058 & .084 & .206 \\
\hline PU6 & .659 & .415 & .075 & .230 & .119 & .095 & .100 & .185 \\
\hline PEU1 & .410 & .626 & .087 & .214 & .109 & .114 & .194 & .101 \\
\hline PEU2 & .496 & .519 & .200 & .155 & .161 & .103 & .122 & .186 \\
\hline PEU3 & .248 & .740 & .147 & .159 & .149 & .092 & .165 & .244 \\
\hline PEU4 & .297 & .668 & .256 & .150 & .159 & .138 & .135 & .174 \\
\hline PEU5 & .247 & .600 & .364 & .060 & .019 & .033 & .312 & .249 \\
\hline PEU6 & .273 & .657 & .311 & .094 & .072 & .051 & .256 & .221 \\
\hline ITU1 & .392 & .315 & .150 & .108 & .082 & .236 & .160 & .616 \\
\hline ITU2 & .181 & .381 & .211 & .092 & .155 & .148 & .118 & .703 \\
\hline ITU3 & .352 & .182 & .256 & .194 & .163 & .133 & .140 & .655 \\
\hline ITU4 & .447 & .211 & .156 & .189 & .200 & .110 & .092 & .596 \\
\hline TS1 & .202 & .264 & .086 & .277 & .549 & .261 & -.042 & .095 \\
\hline TS2 & .201 & -.011 & .114 & .106 & .781 & .118 & .172 & .073 \\
\hline TS3 & .213 & .015 & .144 & .080 & .827 & .097 & .097 & .081 \\
\hline TS4 & .123 & .340 & .044 & .078 & .665 & .208 & .126 & .224 \\
\hline TS5 & .089 & .376 & .230 & .059 & .445 & .438 & .157 & .007 \\
\hline IE1 & .122 & .272 & .278 & .101 & .059 & .236 & .641 & .161 \\
\hline IE2 & .120 & .230 & .187 & .143 & 169 & .099 & .804 & .048 \\
\hline IE3 & .155 & .161 & .140 & .172 & .161 & .128 & .838 & .129 \\
\hline SN1 & .153 & .162 & .268 & .637 & .237 & .135 & .231 & .162 \\
\hline $\mathrm{SN} 2$ & .133 & .225 & .146 & .796 & .146 & .088 & .073 & .088 \\
\hline SN3 & .226 & .111 & .165 & .795 & .061 & .210 & .103 & .099 \\
\hline SN4 & .230 & .028 & .171 & .681 & .055 & .370 & .129 & .077 \\
\hline SI1 & .167 & .102 & .175 & .202 & .175 & .787 & .102 & .094 \\
\hline SI2 & .079 & .036 & .179 & .201 & .201 & .796 & .098 & .107 \\
\hline SI3 & .225 & .116 & .168 & .204 & .147 & .680 & .195 & .188 \\
\hline SE1 & .182 & .296 & .505 & .219 & .243 & .340 & .135 & .217 \\
\hline SE2 & .199 & .278 & .642 & .077 & .152 & .219 & .268 & .159 \\
\hline SE3 & .119 & .264 & .753 & .157 & .144 & .158 & .166 & .166 \\
\hline SE4 & .204 & .117 & .723 & .186 & .062 & .282 & .098 & .097 \\
\hline SE5 & .246 & .129 & .770 & .289 & .114 & .037 & .164 & .121 \\
\hline Eigenvalue & 16.081 & 2.370 & 1.930 & 1.664 & 1.254 & 1.095 & 1.043 & .856 \\
\hline $\begin{array}{c}\text { Cum. Variance } \\
\text { Explained \% }\end{array}$ & 44.669 & 51.253 & 56.613 & 61.234 & 64.718 & 67.758 & 70.655 & 73.032 \\
\hline
\end{tabular}




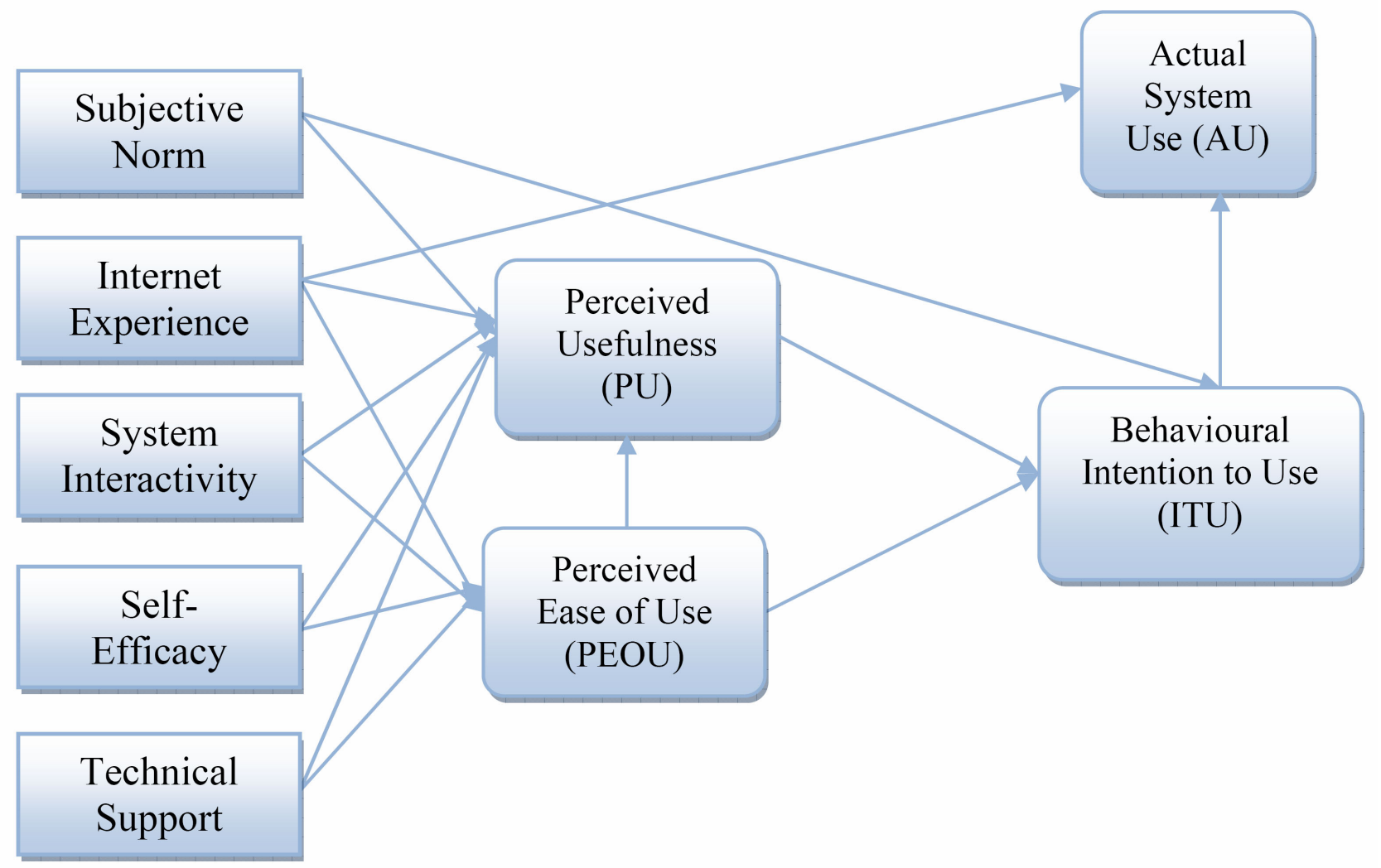

Figure 2. The Modified Research Model

TABLE V.

SEM STATISTICS OF MODEL Fit (ACTUAL USE)

\begin{tabular}{|l|l|l|}
\hline \multicolumn{1}{|c|}{ Model goodness-fit indexes } & \multicolumn{1}{c|}{ Recommended value } & \multicolumn{1}{c|}{ Result in this study } \\
\hline Chi-square & & $504.533 *$ \\
\hline Degree of freedom & & 208 \\
\hline Chi-square/df & $\leq 3.00$ & 2.304 \\
\hline Goodness-of-fit index (GFI) & $\geq 0.90$ & 0.914 \\
\hline Adjusted goodness-of-fit index (AGFI) & $\geq 0.80$ & 0.887 \\
\hline Normalized fit index (NFI) & $\geq 0.90$ & 0.925 \\
\hline Comparative fit index (CFI) & $\geq 0.90$ & 0.956 \\
\hline Root mean square error of approximation (RMSEA) & $\leq 0.08$ & 0.053 \\
\hline Note: $\mathrm{N}=470, * \mathrm{p}<0.05$ & &
\end{tabular}

Note: $\mathrm{N}=470, \quad * \mathrm{p}<0.05$

TABLE VI.

RESULTS OF PATH TESTS

\begin{tabular}{|c|c|c|c|c|}
\hline Path & Hypothesis & Critical Ratio & Sig. Level & Comment \\
\hline $\mathrm{SN} \longrightarrow \mathrm{PU}$ & H1 & 2.647 & 0.008 & Sig. \\
\hline $\mathrm{SN} \longrightarrow \mathrm{ITU}$ & $\mathrm{H} 2$ & 2.742 & 0.006 & Sig. \\
\hline $\mathrm{IE} \longrightarrow \mathrm{PEU}$ & H3 & 4.199 & 0.001 & Sig. \\
\hline $\mathrm{IE} \longrightarrow \mathrm{PU}$ & H4 & -2.280 & 0.023 & Sig. \\
\hline $\mathrm{SI} \longrightarrow \mathrm{PEU}$ & $\mathrm{H} 5$ & 0.019 & 0.985 & Not Sig. \\
\hline $\mathrm{SI} \longrightarrow \mathrm{PU}$ & $\mathrm{H} 6$ & 0.919 & 0.358 & Not Sig. \\
\hline $\mathrm{SE} \longrightarrow \mathrm{PEU}$ & H7 & 7.788 & 0.001 & Sig. \\
\hline $\mathrm{SE} \longrightarrow \mathrm{PU}$ & $\mathrm{H} 8$ & 1.616 & 0.106 & Not Sig. \\
\hline $\mathrm{TS} \longrightarrow \mathrm{PEU}$ & H9 & 1.182 & 0.237 & Not Sig. \\
\hline $\mathrm{TS} \longrightarrow \mathrm{PU}$ & H10 & 4.096 & 0.001 & Sig. \\
\hline $\mathrm{PEU} \longrightarrow \mathrm{PU}$ & H11 & 6.734 & 0.001 & Sig. \\
\hline PEU $\longrightarrow$ JTU & H12 & 7.765 & 0.001 & Sig. \\
\hline $\mathrm{PU} \longrightarrow \mathrm{ITU}$ & H13 & 6.601 & 0.001 & Sig. \\
\hline
\end{tabular}

Note: Significant relationships in bold 